\title{
After-Ripening Increased Seed Germination in Commercial Aubergine Seed Lots
}

\author{
Eren OZDEN* and Ibrahim DEMIR \\ Department of Horticulture, Faculty of Agriculture, Ankara University, 06110-Diskapi/Ankara, Turkey \\ *corresponding author: erozden@ankara.edu.tr
}

Bulletin UASVM Horticulture 75(1) / 2018

Print ISSN 1843-5262, Electronic ISSN 1843-536X

DOI:10.15835/buasvmcn-hort: 002017

\begin{abstract}
This work tested the effect of after-ripening on seed germination of thirteen commercial seed lots from four open pollinated cultivars (Aydın Siyahı, Kemer, Pala and Topan) of aubergine (Solanum melongena L.). Seeds were stored (after-ripened) at $5{ }^{\circ} \mathrm{C}$ with at $9 \%$ seed moisture content over 14 days in the dark in hermetic conditions. After-ripened seeds were tested at $25^{\circ} \mathrm{C}$ and $20 / 30^{\circ} \mathrm{C}(16 / 8 \mathrm{~h})$ together with a control at $20 / 30{ }^{\circ} \mathrm{C}$ for 14 days in petri dishes. Results indicated that after-ripening significantly $(\mathrm{p}<0.05)$ increased total germination in six lots and normal germination in eight lots out of thirteen when germination was tested at $25^{\circ} \mathrm{C}$. Increases were also observed eleven lots in total and thirteen in normal germination percentages out of thirteen when seeds were tested at $20 / 30^{\circ} \mathrm{C}$. Cumulative germination showed that after-ripened seeds germinated faster than control either germinated at 25 or $20 / 30^{\circ}$ C. Results indicated that aubergine seed germination can be increased through afterripening treatment which shows the presence of seed dormancy in this species.
\end{abstract}

Keywords: storage, cumulative germination, dormancy, seed storage temperature, alternating temperatures

\section{Introduction}

Aubergine (Solanum melongena L.) is one of the major field and greenhouse crops in Turkey. For seed production purposes, aubergine fruits should be harvested from the plant 55 days after anthesis and later (Demir et al., 2002). Due to the maturation differences and once over harvesting practices in seed companies, seeds in the same lot can be at different maturation stages (Demir et al., 2002). The reason for this is harvesting fruits at different maturity and mixing seeds in the same batch. In our research experience, aubergine germinates faster at alternating temperatures than at constant ones (Ozden and Demir, 2016a; Ozden et al., 2016b; Ozden et al., 2018). ISTA suggests alternating temperature for ideal germination percentage tests (ISTA, 2016). Storing seeds in the fruit, especially less mature ones enhanced germination percentages (Passam et al., 2010). This indicates that dormancy in aubergine seeds may reduce or delay germination. Therefore, immature seeds require post-harvest maturation which includes alleviation dormancy. After-ripening (dry storage after harvest) is considered as a known dormancy breaking treatment (Lewak and Rudnicki, 1977; IglesiasFernandes et al., 2010) and promoted germination in pepper, another member from the Solanaceae family (Edwards and Sundstrom, 1987). This work was designed to test the effect of after-ripening on seed germination percentages of commercially available aubergine seed lots.

\section{Material and Methods}

Thirteen seed lots of aubergine (Solanum melongena $\mathrm{L}$.) belonging to four different cultivars, 

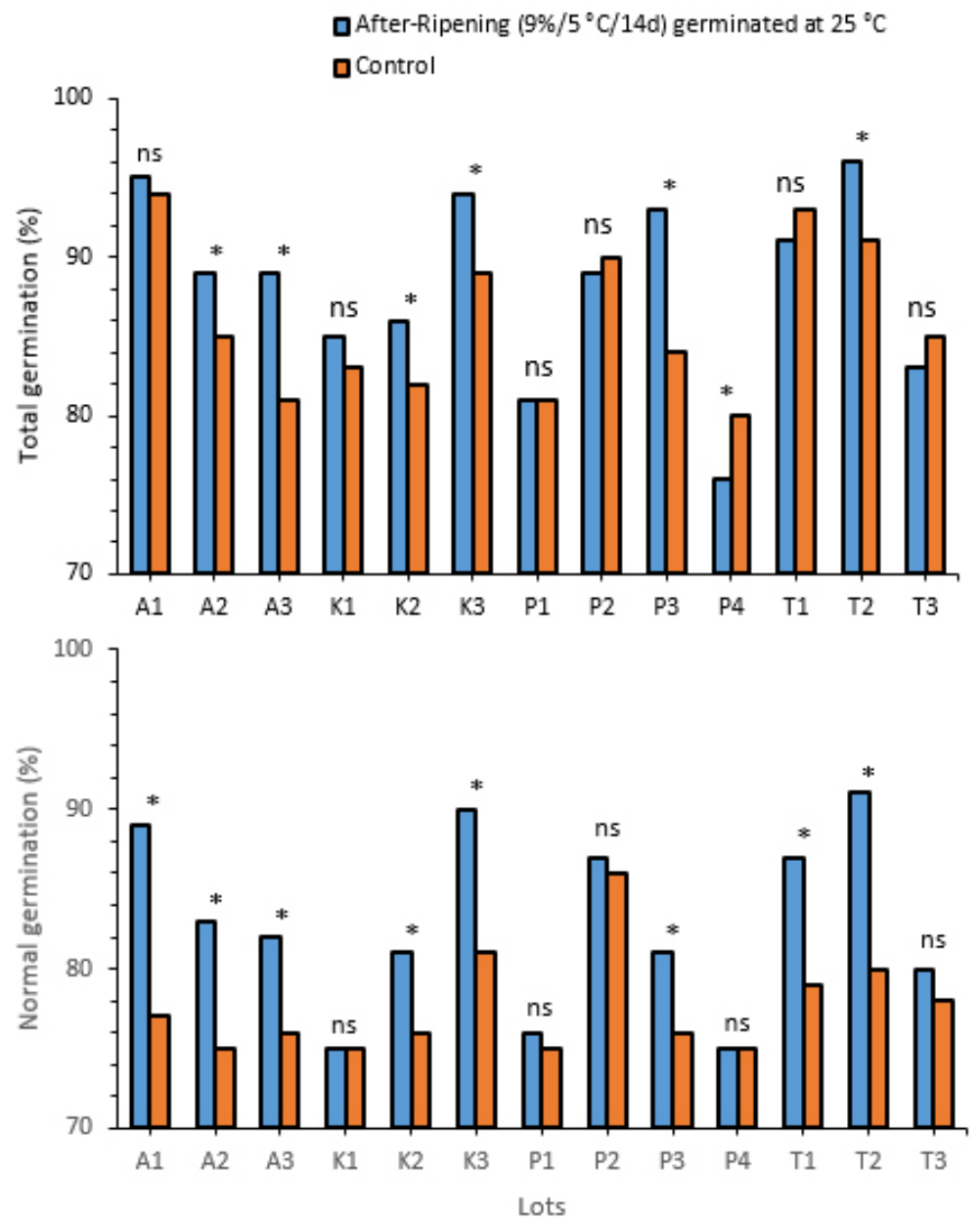

Figure 1. The effect of after-ripening treatment on total and normal germination percentages of 13 commercial aubergine seed lots when germinated at constant $\left(25^{\circ} \mathrm{C}\right)$ temperatureAsterisks show significance at $5 \%$ level between after-ripened and control seeds (ns: not significant)

(3 to Aydın Siyahı, 3 to Kemer, 4 to Pala and 3 to Topan) supplied by various seed companies, were bought in Ankara in March 2016 from retail outlets in which seeds were sold to small scale farmers or growers. These cultivars are the most common and widely grown in open fields in Turkey. Seeds were bought in hermetically sealed, aluminum foil packets.

All seed lots had been treated with thiram powder. Seed moisture content (mc) was determined using the low temperature oven method (ISTA, 2016) on two replicates of $1 \mathrm{~g}$ seeds held at $103{ }^{\circ} \mathrm{C}$ for $17 \mathrm{~h}$; the samples were then allowed to cool in a desiccator for half-an hour. Moisture content was expressed on a fresh weight basis. Initial seed moisture content ranged between 6.9 and $11.1 \%$. Control seeds were considered as those that seed moisture was not raised and kept in foil packets at $5^{\circ} \mathrm{C}$ and germinated at $20 / 30^{\circ} \mathrm{C}$.
After-ripening treatment was performed at 9\% seed moisture content at $5{ }^{\circ} \mathrm{C}$ over 14 days. Two grams of seeds in each lot were weighed (four decimal places) and placed over saturated $\mathrm{NaCl}$ solution which provides $72 \%$ r.h at $20 \pm 1{ }^{\circ} \mathrm{C}$. Seeds were weighed frequently. The seed moisture of aubergine seeds were equilibrated at $9 \pm 0.2 \%$. Those seed lots that seed moisture contents were dried on top of silica gel and desired seed moisture was calculated through frequent weighing. Final seed moisture of the lots was calculated from the initial seed weight and moisture by the following formula:

Seed weight at desired $m c=\frac{(100-\text { initial } m c)}{(100-\text { desired } m c)} \times$ weight of seed

The seeds in each lot were then sealed in aluminum foil packets and kept at $5{ }^{\circ} \mathrm{C}$ over 14 days. After after-ripening germination tests were performed on each lot at two temperatures; 25 

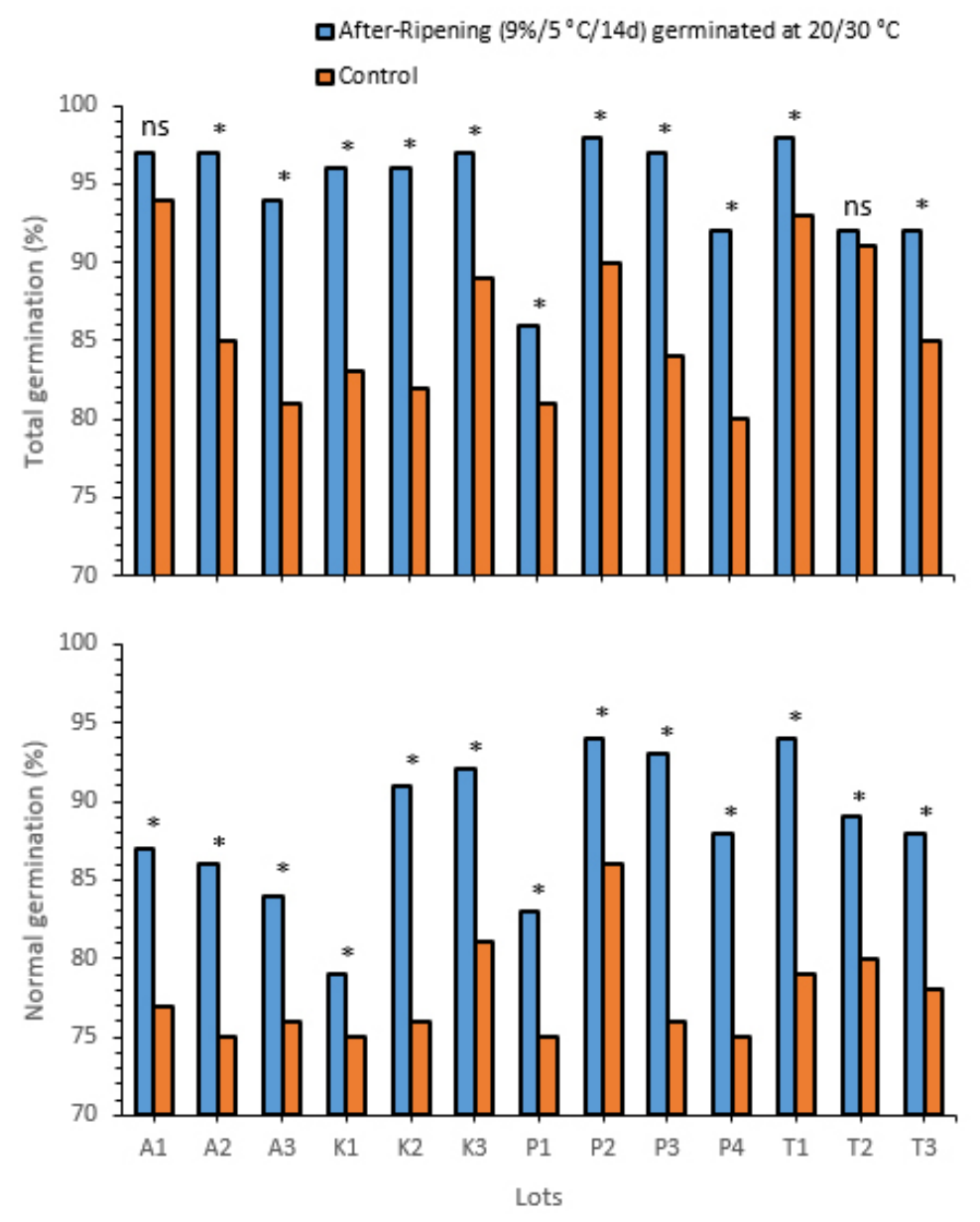

Figure 2. The effect of after-ripening treatment on total and normal germination percentages of 13 commercial aubergine seed lots when germinated at alternating temperatures $\left(20 / 30^{\circ} \mathrm{C}, 16 \mathrm{~h} / 8 \mathrm{~h}\right)$. Asterisks show significance at $5 \%$ level between after-ripened and control seeds (ns: not significant)

${ }^{\circ} \mathrm{C}$ or $20 / 30{ }^{\circ} \mathrm{C}(16 \mathrm{~h} / 8 \mathrm{~h})$. Each of four replicates of 50 seeds per lot was placed in a Petri dish on germination paper (Whatman No: $5,9 \mathrm{~cm}$ ) moistened with $2 \mathrm{ml}$ of distilled water. The Petri dishes were then placed in plastic bags in order to prevent water loss during the test and held at $25 \pm 1{ }^{\circ} \mathrm{C}$ or alternating temperatures of $20 / 30$ ${ }^{\circ} \mathrm{C}$. Seed germination ( $2 \mathrm{~mm}$ radicle emergence) was counted daily for 14 days. At the final count, seedlings were classified as normal and abnormal (ISTA 2016). The mean germination times (MGT) were calculated on the basis of daily radicle protrusion counts using the following formula:

\section{$\mathrm{MGT}=\sum \mathrm{n} \cdot \mathrm{D} / \sum \mathrm{n}$}

where, $n=$ number of seeds newly germinated ( $2 \mathrm{~mm}$, radicle emergence) at time $\mathrm{D}$ at $25{ }^{\circ} \mathrm{C}$ and alternating temperatures of $20{ }^{\circ} \mathrm{C} / 30{ }^{\circ} \mathrm{C}, \mathrm{D}=$ days from the beginning of the germination test, $\Sigma \mathrm{n}=$ final germination.
Statistical analysis was performed by using SPSS to perform ANOVA analyses. Comparison of means was made at $5 \%$ level. Means of treated and control seeds in each cultivar were compared by $\mathrm{t}$ test. Percentages were arcsine transformed prior to analysis.

\section{Results}

Experimental results showed that afterripening aubergine seed lots increased total (radicle emergence) and normal germination percentages (normally developed seedlings) either in germinating at constant or alternating temperatures. six lots in total and eight lots in normal germination percentages had significantly $(\mathrm{p}<0.05)$ higher values than control when seeds were germinated at $25{ }^{\circ} \mathrm{C}$. Similar results were found 11 in total and 13 lots in normal germination percentages out of 13 lots. More 


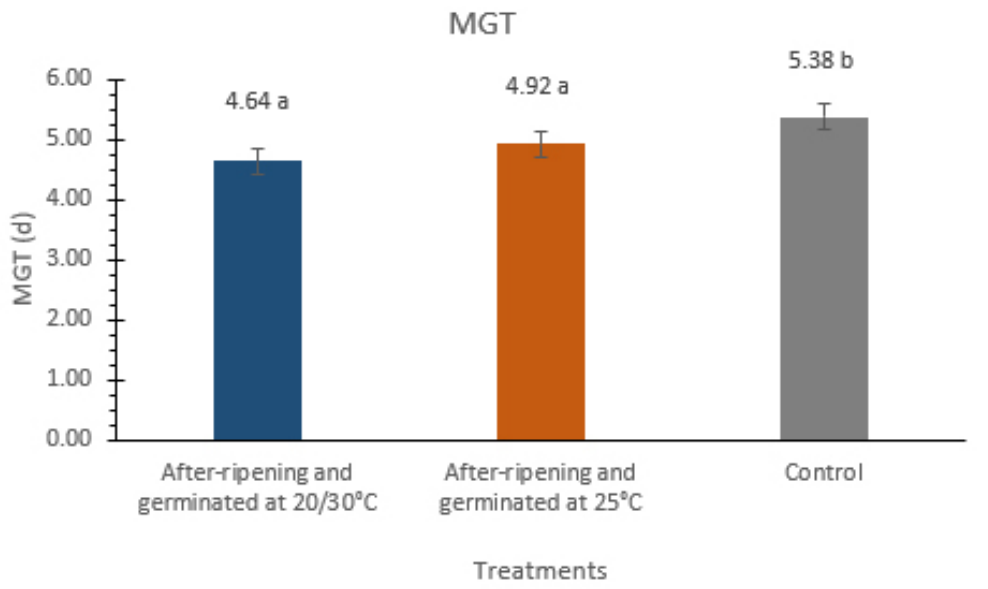

Figure 4. The effect of after-ripening on Mean germination time (d) of 13 commercial aubergine seed lots when germinated at constant or alternating temperaturesSEM values were shown as bars in each columnSignificance between the values were indicated with different letters at 5\%

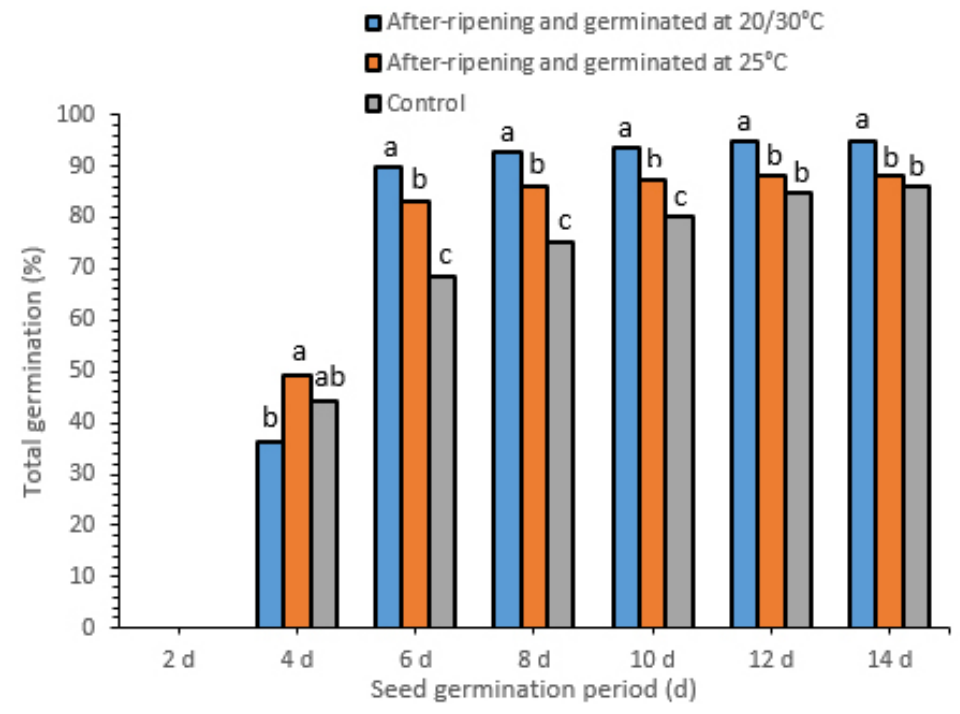

Figure 3. Cumulative germination percentages of 13 aubergine seed lots during 14 days when after-ripened and germinated at constant $\left(25^{\circ} \mathrm{C}\right)$, alternating temperatures $\left(20 / 30{ }^{\circ} \mathrm{C}, 16 \mathrm{~h} / 8 \mathrm{~h}\right)$ or not after-ripened and germinated at $20 / 30{ }^{\circ} \mathrm{C}(16 \mathrm{~h} / 8 \mathrm{~h})$. Values with the different letters in each period are significantly different at $5 \%$

seed lots responded to after-ripening when germinated at alternating temperatures than at constant temperature (Fig. 1 and 2). Not only seed germination but also germination rate expressed as mean germination time, were found significantly higher in after-ripened seed lots $(\mathrm{p}<$ 0.05 ) than that of control.

Cumulative germination percentages in germination time showed that after-ripened seeds started germination earlier than that of control when they germinated at either $25{ }^{\circ} \mathrm{C}$ or alternating temperatures (Fig. 3). By the day 6 the mean total germination percentage in between after-ripened and control seeds were 16 and $22 \%$ when germination was performed at 25 ${ }^{\circ} \mathrm{C}$ and $20 / 30{ }^{\circ} \mathrm{C}$, respectively. The cumulative germination percentages were also found to be higher at alternating temperatures than that at constant temperature throughout the germination period (Fig. 3).

Mean germination time of afterripened seeds were 4.92 and 4.64 days when germinated at 25 and $20 / 30{ }^{\circ} \mathrm{C}(16 \mathrm{~h} / 8 \mathrm{~h})$, respectively (Fig. 4). Mean 
Table 1. Changes in normal germination percentages, initial seed moisture content production year in 13 commercial seed lots after-ripened and germinated at constant or alternating temperatures

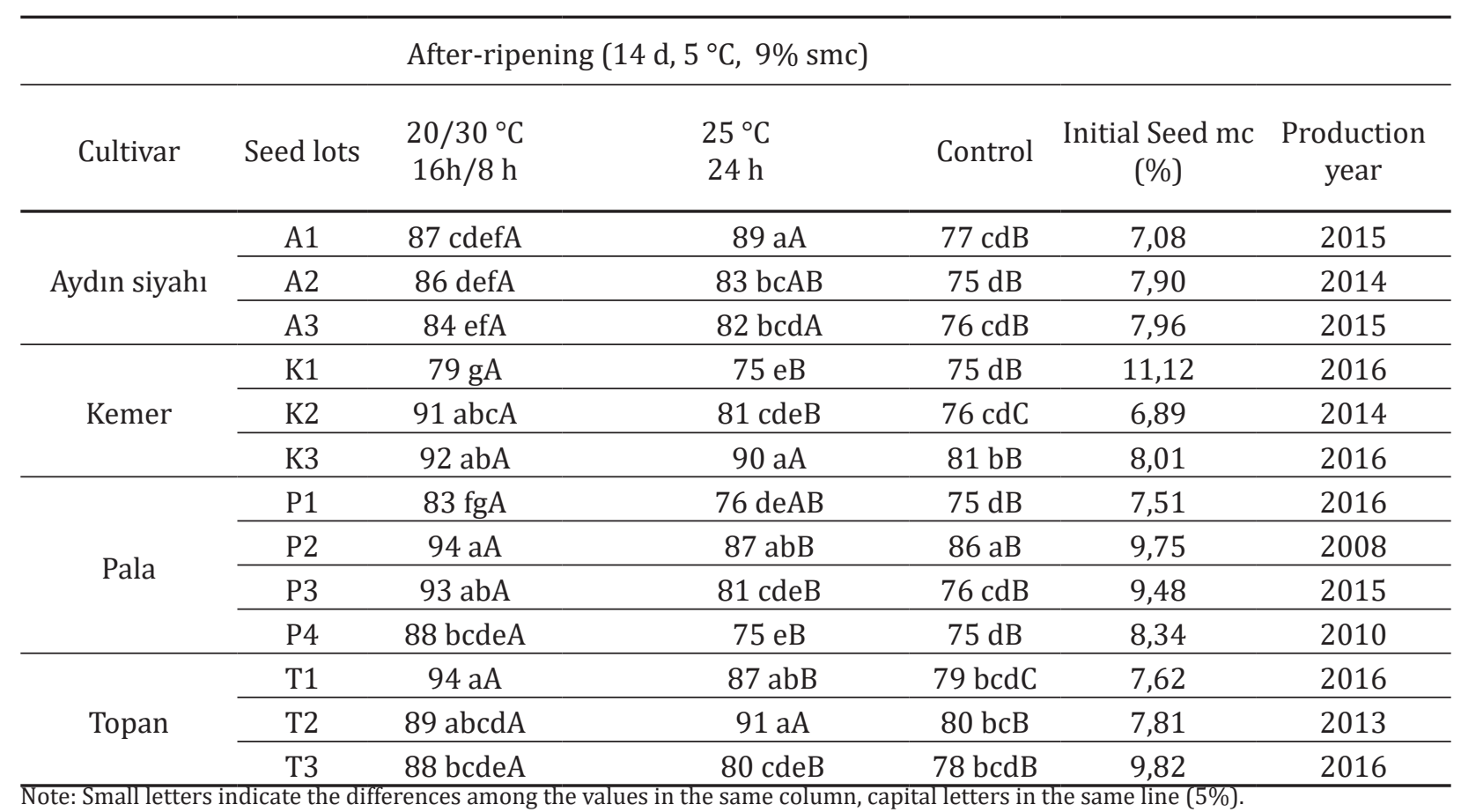

germination time in control seeds was found as 5.38 days.

Seed lots used in this work belong to the four cultivars. The advantage of afterripening in each cultivar differed. The P3 seed lot, belonging to Pala, had the highest advantage in normal seedling percentages at $17 \%$ and the lowest in $\mathrm{A} 1$ belonging to Aydın Siyahı as $12 \%$ when germinated at alternating temperatures $\left(20 / 30{ }^{\circ} \mathrm{C}-16 \mathrm{~h} / 8 \mathrm{~h}\right)$ (Tab. 1).

\section{Discussion}

This work showed that after-ripening treatment increased germination percentages and reduced germination time in commercial aubergine seed lots. This was more significant when seeds are germinated at alternating temperatures compared with constant ones. The cultivars responded differently to the afterripening treatment, but particularly at alternating temperatures normal germination percentages of all seed lots were increased by the after-ripening.

After-ripening is considered as a main dormancy breaking treatment (Lewak and Rudnicki, 1977; Iglesias-Fernandes et al., 2010). Even though it is more commonly used in cereals, it was also studied to enhance seed quality and release partial dormancy in aubergine (Yogeesha et al., 2006). Seeds kept in the less mature fruits during seed development (Passam et al., 2010) had higher germination percentages than those harvested immediately. Leaving seeds in the fruit increased germination particularly those of less mature fruits. Similar findings were reported in another member of Solanacea family, in peppers (Edwards and Sundstrom, 1987). In this work we used the commercial seed lots in which seeds are likely to be at various maturation stages due to the once-over harvesting (harvesting all fruits at the same time). Seed companies in general harvest fruits at the same time and mix the seeds in the same lot. So less mature seeds may have dormancy due to the insufficiently developed embryo and low seed weight in the same batch (Demir et al., 2002). Various physiological events can be related to release of dormancy and germination increase (Iglesias-Fernandes et al., 2010). One of these is decrease in Abscisic acid content during seed storage. Yogeesha et al. (2006) found that 12 months of dry storage reduced ABA content from $60 \mathrm{ng} / \mathrm{g}$ in the control to $20 \mathrm{ng} / \mathrm{g}$ in one and from $40 \mathrm{ng} / \mathrm{g}$ to $20 \mathrm{ng} / \mathrm{g}$ in the other dormant aubergine cultivar seeds. 
Alternating temperatures are able to induce germination in many species (Ellis and Barret, 1994). ISTA (2016) also suggest alternating temperature for standard germination in aubergine. The higher germination percentages at alternating temperatures in 13 aubergine seed lots indicated that they help to release some dormancy is supporting the earlier findings (Demir and Okcu, 2005, Passam et al., 2010).

Cultivars differ in their response to afterripening treatment. The lots belong to the different companies. These companies produced seeds in different regions. This can be attributed to the earlier harvest practices and genetic variation (Demir et al., 2002). We did not produce seed lots so not much information was available about lots. However, aubergine seeds are produced in various geographic regions of Turkey. So a further work may relate occurrence of dormancy and growing region.

As a result, aubergine seed germination can be increased through after-ripening treatment by storing at $5{ }^{\circ} \mathrm{C}$ over 14 days with $9 \%$ seed mc and germination at alternating temperature. This is a simple and practically usable method to increase the germination which can be used just before the use of seeds in germination or seedling production.

\section{References}

1. Demir I, Mavi K, Sermenli T, Ozcoban M (2002). Seed development and maturation in aubergine. Gartenbauwissenschaft, 67(4): 148-154.

2. Demir I, Okcu G (2005). Effect of post-harvest maturation treatment on germination and potential longevity of pepper (Capsicum annuum) seeds. Indian Journal of Agricultural Sciences, 75(1): 19-22.
3. Edwards RL, Sundstrom FJ (1987). Afterripening and harvest effects on Tabasco pepper seed germination performance. HortScience, 22(3): 473-475.

4. Iglesias-Fernandez R, Carmen Rodriguez-Gacio M, Matilla AJ (2010). Progress in research on dry afterripening. Seed Science Research, 20: 1-12.

5. Ellis RH, Barret S (1994). Alternating temperatures and rate of seed germination in lentil. Annals of Botany, 74: 519-524.

6. ISTA (2016). International Rules for Seed Testing, International Seed Testing Association, Bassersdorf, Switzerland.

7. Lewak S Rudnicki RM (1977). After-ripening in cold requiring seeds. In: The Physiology and Biochemistry of Seed Dormancy and Germination. Elsevier North Holland Biomedical Press (pp. 193-217).

8. Ozden E, Demir I (2016a). Ga3 Enhanced Seed Germination of Solanum torvum. Radovi Poljoprivrednog Fakulteta Univerziteta u Sarajevu. 66(1): 316-320.

9. Ozden E, Ermis S, Bastabak B, Demir I (2016). Değișken Sıcaklık Uygulamalarının Bazı Patlıcan Çeşitlerinde Çimlenme Oranı ve Çimlenme Hızı Üzerine Etkileri. Bahçe Yalova Atatürk Bahçe Kültürleri Merkez Araștırma Enstitüsü Dergisi. 45(2): 414-416.

10. Ozden E, Ozdamar C, Demir I (2018). Radicle Emergence Test Estimates Predictions of Percentage Normal Seedlings in Standard Germination Tests of Aubergine (Solanum melongena L.) Seed Lots. Notulae Botanicae Horti Agrobotanici Cluj-Napoca. 46(1): 177-182. Doi:http://dx.doi.org/10.15835/nbha46110871

11. Passam HC, Theodoropoulou S, Kranissa T, Karapanos IC (2010). Influence of harvest time and after-ripening on the seed quality of eggplant. Scientia Horticulturae, 125: 518-520.

12. Yogeesha HS, Upreti KK, Padmini K, Bhanuprakash K, Murti GSR (2006). Mechanism of seed dormancy in eggplant (Solanum melongena L.). Seed Science and Technology, 34: 319-325. 